\title{
A Study of Emotional Regression and Social Adjustment in Youth
}

\section{Gondalia Daxaben D.}

Ph. D. Scholar, Department of Psychology, Saurashtra University, Rajkot, Gujarat, India

\begin{abstract}
The Present Study aims at finding out whether there are any differences in emotion regression and Social adjustment between young males and females the subjects were 60 young males \& females a significant difference was found between males \& females with respect to Social Adjustment. But no such significant level was found on emotional regression.
\end{abstract}

Keywords : Emotional Regression and Social Adjustment

\section{INTRODUCTION}

Emotional regression, before us saying about it we must know the meaning of emotion after we can define the meaning of Emotional Regression.

\section{What is the Meaning of Emotion?}

Emotion is a strong experience of physical and psychological. The impact of emotion on person is type of psychosomatic, therefore Wood worth says,

"Emotion is a stirred up state of the individual."

Emotion word comes from Latin word "Emovere" which means is basically to be exited.

"Emotion is a complex way of behaving in which the various component are in - targeted about the integrated about the internal reaction.

-Horace English.

\section{What is Regression?}

Regression is a word that is often used to describe someone who has fallen back into their old ways. The meaning of transgression could be described as going backwards or getting worse. Regression where health is concerned means that the health is getting worse instead of better. The same can be said for the heart of the human being.

Regression is also used often in the religious world. Such as "He regressed back into his sing of old". This is as good example that regression is the act of falling backwards instead of moving forward in life. You must always move forward to avoid regression. Never stand still in what you are doing and never look backwards. Looking back causes us to sometimes fall backwards.

Falling backwards is never a good thing. Regression rears it's ugly head then. Regression is generally used as a negative term about something or someone. In fact, most people would find it hard to remember a time that they backwards, falling into old ways, all of these are negatives. 
An alcoholic may stop drinking but has the chance of falling back into it. The regression to alcoholism is bad for the health and well being of those who live with it. If an alcoholic quits drinking, he is progressing. If he starts again, he is regressing. Which is better for him? The positive word is of course. Progress is always better than regress.

\section{Social Adjustment}

Human beings never remain entirely adjusted biological and social needs are too. Persistent and are changing with new inventions and technological progress our society changes. Furthermore, we are limited in time and abilities and cannot satisfy all the needs that arise. Adjustment is a continuous process. the dead man is the only complete adjustment might be undesirable, the individual who constantly remains in fair Adjustment to his environment has been referred "bovine" plasticity of behavior amid continuity seems to be a more desirable condition.

\section{Definition of Social adjustment}

"Adaptation of the person to the social environment. Adjustment may take place by adapting the self to the environment or by changing the environment." (From Campbell, Psychiatric Dictionary, 1996).

You remain Adjusted to your environment depends on how much you and it change. In evaluating out adjustment we must consider all our motives (urges, wishes and tendencies) used to satisfy out organic social and personal demands. we must consider our entire personality.

According to M. Basavanna's dictionary of psychology.

Adjustment is a general term that refer to an individual's ability and meet the demands of society and satisfy his her own needs.”
Bromley (1966) ha gave a comprehensive description of good and poor Adjustment. According to him " a well adjusted person is likely to be physically fit active and me tally alert for his age, his morale is high and he will be fairly confident is social relationships. He will be relaxed and satisfied with the way things go on. He will be effective in overcoming socially acceptable satisfaction and achievements good adjustment expresses itself in happiness confident. Contentment, sociability, freedom from morbid emotions, self esteem and productive activity. Adjustment is poor it the individual cannot overcome frustrations, resolve conflict or achieve satisfying results through socially acceptable from of behavior. poor Adjustment is expressed in hostility, unhappiness, fear of people discontent morbid anxiety, withdrawal and incompetence."

In short, Adjustment may define as a process of altering one's behavior to reach a harmonious relationship with the environment. When people say they are I on "Adjustment period" they typically mean they are going through a process of change and are searching for some level of balance or acceptance with the environment, others or themselves.

\section{METHODS AND MATERIAL}

\section{Research Problem.}

A study of Emotional Regression and social Adjustment in Youth.

\section{Research Objects.}

To find out emotional Regression in youngsters (male-female)

To find out Social V Adjustment In youngsters (malefemale) 


\section{Hypotheses}

1) There will be no significant difference between Emotional regression of young males and females.

2) There will be no significant difference between Social adjustment of young males and females

\section{Research variables}

\section{Independed variable}

Gender (male- female)

\section{Depended variable}

Score of Emotional Regression and Social Adjustment are in depended variables.

\section{Research samples.}

The present sample comprised of 60 young males and females. in which 30 were male and 30 were female youngsters They were selected randomly from different area of Rajkot city.

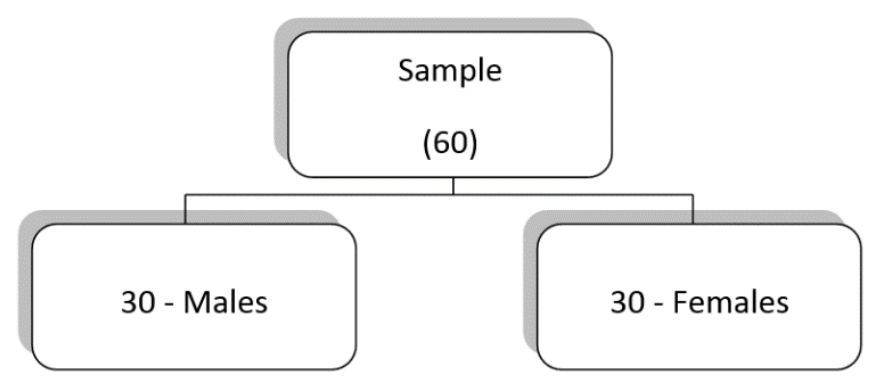

\section{Research Tools.}

\section{(A) Emotional Regression Scale}

Emotional Regression scale developed by Mahesh Bhargava, it consists of 10 items; each item has five levels or response. Ranging from high to low degree.

\section{(B) Social Adjustment Scale}

Social Adjustment questionnaire developed by Bell which is translated by Dr. D. J. Bhatt, that translated scale has been used It has 32 items, lower score on this scale is indicative of better Social Adjustment.

\section{RESULTS AND DISCUSSION}

The main aim of present study was investigate the significance of difference between young males and females and in terms of emotion regression and social adjustment.

Table -1. Comparison between young males and females on Emotion Regression

\begin{tabular}{|c|c|c|c|}
\hline VARIABLES & $\begin{array}{l}\text { EMOTION } \\
\text { REGRESSION } \\
\text { SCORE }\end{array}$ & \multirow[t]{2}{*}{$\mathrm{T}$} & \multirow[t]{2}{*}{ SIG. } \\
\hline & MEAN S.D. & & \\
\hline MALE (N=30) & $\begin{array}{l}23.77 \\
6.93\end{array}$ & \multirow[t]{2}{*}{0.80} & \multirow[t]{2}{*}{ NS } \\
\hline $\begin{array}{c}\text { FEMALE } \\
(\mathrm{N}=30)\end{array}$ & $\begin{array}{l}22.27 \\
5.32\end{array}$ & & \\
\hline
\end{tabular}

First null hypothesis formulated was that there will be no significant difference between emotion regression of young males and females Table-1 reveals that $(0.80)$ value is insignificant the first null hypothesis is therefore accepted.

Table -2 Comparison between young males and females on Social Adjustment

\begin{tabular}{|c|l|c|c|}
\hline VARIABLES & $\begin{array}{l}\text { SOCIAL } \\
\text { ADJSTMENT } \\
\text { SCORE }\end{array}$ & T & SIG. \\
\cline { 2 - 2 } & MEAN S.D. & & \\
\hline MALE (N=30) & 32 & 2.46 & 0.01 \\
& 7.14 & & \\
\hline FEMALE & 27.53 & & \\
$(\mathrm{~N}=30)$ & 6.75 & & \\
\hline
\end{tabular}


Further it was hypothesized that there will be no significant level between social adjustment of young males and females Table- 2 indicates that young males significantly differ from young females on social adjustment at 0.01 lever of significance and the mean value show that young males scored higher that the young females as per scoring of scale indicate that lower score means better social adjustment on according to the scale high score of young males indicates less social adjustment than females, thus, second null hypothesis was rejected so, it proves young males have some adjustment problems.

\section{IV.CONCLUSION}

It may ne concluded that young females have significantly, better social adjustment than the young males but, there is no significant between emotion regression on young males and females.

\section{REFERENCES}

[1]. English H.B. (1995-96) quoted from child psychology c. Jamanadas \& Co. Page No. 73,788 .

[2]. Social Adjustment Definition: From Campbell, Psychiatric Dictionary, (1996)

[3]. M.Basavanna, Dictionary of Psychology applied publishers limited, 2000

[4]. Bromley D. B. (19740, The Psychology of Human aging London. Penguin Book Ltd.

[5]. Social adjustment View points: "Problems \& pattern of adjustment A Study of old people in Gujarat." - By Anand Vyas from veer Nar mad south Guj. University.
Cite this article as :

Gondalia Daxaben D., "A Study of Emotional Regression and Social Adjustment in Youth", International Journal of Scientific Research in Science and Technology (IJSRST), Online ISSN : 2395-602X, Print ISSN : 2395-6011, Volume 6 Issue 1, pp. 521-524, January-February 2019. Available at doi : https://doi.org/10.32628/IJSRST196224 Journal URL : http://ijsrst.com/IJSRST196224 